PUBLIPRENEUR POLIMEDIA: JURNAL ILMIAH JURUSAN PENERBITAN

POLITEKNIK NEGERI MEDIA KREATIF

Vol. 8, No. 2, December 2020 hal. 1-10

Submitted: 25 July 2020

- Revised: 15 October 2020

Accepted: 20 December 2020

\title{
ISLAMIC CONTRIBUTIONS IN THE FIELDS OF ART AND SCIENCE
}

\author{
Elok Faiqoh ${ }^{*}$, Najmawati Sulaiman ${ }^{2}$. \\ 1Politeknik Negeri Media Kreatif \\ 2Politeknik Negeri Media Kreatif \\ E-mail: elok_faiqoh@polimedia.ac.id ${ }^{1}$, najmawati_Sulaiman@polimedia.ac.id ${ }^{2}$
}

\begin{abstract}
The discussion of islamic contributions in the fields of art and science is very much embedded in the history of islamic civilization and culture. The rapid growth of Islam is recognized as a most influential civilization. Through this study, researchers invited readers to learn more about the contribution of Islam to the development of world civilization in both the fields of art and science. Descriptive research is used in this study because the information used in this study is wordplay rather than numerical figures obtained from the yellow scriptures, journals, magazines, newspapers, and books. The form of islamic contribution in arts by al-Ghozali talks about the art law itself being poured in his magnum opus (his masterpiece) of Ihya' 'Ulumuddin'. Whereas in science there are al-Khawarizmi with its discovery in the books of al-Jam'a wal Tafriq bil Hisab alHindi, al-falaki with astrological predictions in the books of al- 'uluf, ibn haytam and alkhoziny with optical and gravitational theories in the books of al-manadzir and mizanul hikmah, ar-razi the discoverer of fontanel's thread, in modern sociology ibn khaldun with the work of the Muqaddimah, and Avicenna in medicine of the Qanun fi at-Tib.
\end{abstract}

Keyword: Islamic contribution, art, and science

\section{KONTRIBUSI ISLAM DALAM PERKEMBANGAN SENI DAN SAINS}

\begin{abstract}
ABSTRAK
Pembahasan mengenai kontribusi Islam dalam bidang seni dan sains sangat melekat dengan pembahasan sejarah peradaban dan kebudayaan Islam. Pesatnya pertumbuhan Islam diakui sebagai sebuah peradaban yang paling berpengaruh. Melalui penelitian ini, peneliti mengajak pembaca untuk mengetahui lebih banyak mengenai kontribusi Islam dalam perkembangan peradaban dunia baik dalam bidang seni maupun sains. Penelitian deskriptif digunakan dalam penelitian ini sebab informasi yang dipakai dalam penelitian ini berupa uraian kata dan bukan dalam bentuk angka yang didapat dari kitab-kitab kuning, jurnal, majalah, surat kabar, dan buku. Bentuk kontribusi Islam dalam bidang seni oleh Imam Ghozali membahas tentang hukum seni itu sendiri yang dituangkan dalam
\end{abstract}


magnum opusnya Ihya' 'Ulumuddin. Sedangkan dalam bidang sains ada alKhawarizmi dengan penemuan aljabarnya dalam kitab al-Jam'a wal Tafriq bil Hisab al-Hindi, al-Falaki dengan ramalan-ramalan perbintangan dalam kitab al'Uluf, Ibnu Haytam dan al-Khoziny dengan teori optik dan gravitasi dalam kitab al-Manadzir dan Mizanul Hikmah, ar-Razi penemu benang fontanel, Ibnu Khaldun dalam bidang sosiologi modern dengan karya kitab Muqaddimah, dan Ibnu Sina dalam bidang kedokteran dalam kitab Qanun fi at-Tib.

Kata kunci: Kontribusi Islam, Seni, dan Sains

\section{PENDAHULUAN}

Pembahasan

kontribusi Islam dalam proses perkembangan seni dan sains sangat melekat dengan pembahasan sejarah peradaban dan kebudayaan Islam. Pertumbuhan Islam mulai abad XIV ikut serta mewarnai pertumbuhan peradaban dunia baik dalam seni dan sains. Bahkan pesatnya pertumbuhan Islam diakui sangat cemerlang dan merupakan sebuah peradaban yang paling berpengaruh. Beberapa jejak kecemerlangan peradaban Islam pada masa itu dapat dilihat sebagaimana berikut: adanya badan-badan keilmuan, perpustakaan Islam, dan peninggalan hasil karya ilmuwan muslim seperti Ibnu Khaldun, Ibnu Sina (Avicenna), dan Ibnu Haytam, serta penemuan intelektual yang mampu mempengaruhi adat dan tradisi ummat Islam.

Seni sendiri merupakan sebuah ungkapan jiwa yang mencakup keindahan tarian, syair, nyanyian, lukisan, dan peragaan di panggung, selama memenuhi unsur keindahan. Seni bisa berupa bentuk dan cara apapun, selagi arah tujuannya mampu membawa manusia ke dalam nilai-nilai luhur dan tidak bertentangan dengan nilai-nilai universal yang diajarkan Islam. Rasulullah saw, bersabda: "Allah Maha Indah menyukai keindahan," Allah menganugerahi Bani Adam dengan fitrah untuk menyenangi sebuah keindahan, oleh sebab itu mustahil seni dilarang-Nya, kecuali apabila terdapat unsur luar yang menyertai seni itu. John Hospers menyatakan bahwa seni meliputi setiap benda yang dibuat oleh manusia untuk dibandingkan dengan benda alam.

M. Quraish Shihab berpendapat bahwa seni Islam dimaksudkan sebagai sebuah ungkapan wujud keelokan dari sudut pandang Islam tentang kehidupan, alam, dan manusia yang mampu menuntun dan mempertemukan antara keindahan dan kebenaran. Menurut Yusuf Qardhawi, seni adalah merasakan dan mengungkapkan keindahan. Sedangkan bahasa sederhana pengertian seni menurut Sayyed Hossen Nashr adalah sebuah keahlian mengaktualisasikan ide dan pemikiran estetika dalam penciptaan suasana, benda, atau karya yang dapat 
memunculkan rasa indah dengan berpedoman kepada sumber hukum Islam yang utama. Islam sendiri sesungguhnya hanya memberikan acuan dan arahan, namun tidak menentukan bentuk dari kesenian Islam. Sebab itu, seni Islam bukan bersumber dari entitas tunggal yakni kitab suci, melainkan juga berhubungan dengan seni budaya yang berkembang pada masyarakat.

Melalui penelitian ini, peneliti mengajak pembaca untuk mengetahui lebih banyak tentang kontribusi Islam terhadap perkembangan seni dan sains yang berdampak pada perkembangan peradaban dunia secara keseluruhan. Para sarjana muslim telah banyak mewariskan teori-teori tentang ilmu pengetahuan dan cara penerapannya.

\section{METODE PENELITIAN}

Penelitian deskriptif digunakan dalam penelitian ini sebab informasi yang dipakai dalam penelitian ini berupa uraian kata dan bukan dalam bentuk angka yang didapat dari jurnal, majalah, surat kabar, atau buku. Informasi yang terkumpul tersebut kemudian diuraikan secara rinci. Sedangkan pendekatan yang digunakan adalah pendekatan sosial historis yaitu menela'ah kejadiankejadian di masalalu. Penelitian ini digunakan untuk mengetahui peran dan kontribusi Islam dalam perkembangan peradaban seni dan sains.

\section{HASIL DAN PEMBAHASAN}

Tujuan akhir dari semua ilmu pengetahuan dan kebudayaan harus dilandaskan pada Al-Qur'an dan Hadist. Dalam perkembangannya, seni dan budaya sering ditafsirkan berbedabeda sehingga memiliki pengertian yang beragam. Menurut Sudjoko (1988), bagian-bagian yang wajib terkandung dalam seni adalah cakap, pandai, terampil, ahli, tangkas, dan mahir. Sebagaimana ilmu dan agama yang tidak mudah dideskripsikan dengan sederhana, seni sangat sulit untuk diberikan batasan cakupannya.

Perkembangan seni dan budaya Islam dimulai sejak pemerintahan Dinasti Umayyah, ketetapan al-Malik untuk mengubah bahasa tata kelola dari bahasa Pahlawi dan Yunani ke dalam bahasa Arab, menarik minat masyarakat untuk belajar. Pada masa ini, lahirlah satrawan-satrawan, seperti; Al-Farasdaq (w. 732M), Umar bin Abi Robi'ah (w. 719M), Jamil alUdhri (w. 701M), dan Qais bin alMulawwah (w. 699M). Bukan itu saja, ketertarikan terhadap ilmu kalam, hadist, ilmu tafsir, dan fikih juga mulai tumbuh pada periode ini.

Dinasti Abbasiyah menjadikan perkembangan Islam semakin cemerlang setelah menggantikan kepemimpinan Dinasti Umayyah. Pada periode pemerintahan Abbasiyah ketertarikan terhadap sains semakin meningkat, terlebih pada periode khalifah al-Ma'mun dan sang ayah 
khalifah Harun ar-Rasyid yang penerjemahan karya-karya ini, khalifah diketahui banyak melakukan kegiatan al-Ma'mun membangun lembaga baitul menterjemahkan tulisan-tulisan dan hikmah, adapun ilmu-ilmu karya-karya dari bahasa Byzantium pengetahuan yang menjadi prioritas dan Yunani ke dalam bahasa Arab. adalah optik, sejarah, filsafat, geografi, Untuk menyokong aktivitas fisika, astronomi, dan kedokteran.

Tabel 1 Bukti Kemajuan Peradaban Seni dan Budaya Islam Dari Masa Ke Masa

\begin{tabular}{ccc}
\hline No & $\begin{array}{c}\text { Masa } \\
\text { Pemerintahan }\end{array}$ & Uraian \\
\hline 1 & Dinasti & 1. Perhatian terhadap bahasa Arab semakin besar \\
& Umayyah & 2. Lahirnya sastrawan-sastrawan Arab \\
& & 3. Perhatian terhadap ilmu kalam, tafsir, fiqih dan hadist \\
& & mulai tumbuh \\
\hline 2 & Dinasti & Perkembangan ilmu pengetahuan meliputi: geografi, \\
& Abbasiyah & fisika, astronomi, kedokteran, filsafat, dan sejarah \\
& & Kegiatan menerjemahkan buku-buku berbahasa Yunani \\
& & dan Byzantium ke dalam bahasa Arab
\end{tabular}

Muhammad al-Ghozali (w. 1111M) menjadi satu dari beberapa ulama' yang sangat tertarik dengan dunia seni. Dalam karya fenomenalnya, Ihya' Ulumuddin, al-Ghozali secara khusus menulis satu bab yang membahas tentang kesenian. Al-Ghozali mempelajari, membedah, dan menyumbangkan pemikiran dan penilaiannya kepada pandangan para tokoh tentang kesenian bermusik. Menurut pandangan al-Ghozali, tokoh ulama' berbeda pendapat tentang hukum musik. Sebagian ulama' seperti Imam Syafi'i, Abu Hanifah, Imam Malik, Abu Sufyan, dan at-Thabari mengharamkan musik.

Pengharaman didasarkan pada pendapat bahwa musik dianggap sebagai salah satu alat yang dapat membuat manusia lalai terhadap Tuhannya dan memicu munculnya kemaksiatan. Hal ini dapat dipahami bahwa keharaman musik itu bukan karena musik itu sendiri, melainkan hal-hal yang menyertai musik. Inilah yang kemudian menjadi hujjah pengharaman musik. Bahkan, Imam Syafi'i berpendapat bahwa menabuh-nabuh dengan stik atau tongkat makruh hukumnya. Orangorang Zindiq seing melakukan kegiatan ini, sehingga melupakan untuk membaca ataupun menghafal Qur'an.

Disamping itu, menurut Muhammad bin Salim selain dianggap dapat 


\begin{tabular}{|c|c|c|c|c|}
\hline & $\begin{array}{c}\text { Bidang } \\
\text { Seni }\end{array}$ & Tokoh Islam & Bentuk Kontribusi & Karya \\
\hline 1 & Musik & $\begin{array}{l}\text { Muhammad al- } \\
\text { Ghozali (w. 1111) }\end{array}$ & Hukum bermusik & $\begin{array}{l}\text { Kitah Ihya' } \\
\text { ‘Ulumuddin }\end{array}$ \\
\hline 2 & & $\begin{array}{l}\text { Khalifah Abdul } \\
\text { Malik }\end{array}$ & $\begin{array}{l}\text { Merubah bahasa tata kelola } \\
\text { menggunakan bahasa Arab }\end{array}$ & \\
\hline 4 & Bahasa & $\begin{array}{l}\text { Qais bin al- } \\
\text { Mulawwah (w. } \\
\text { 699M), } \\
\text { Jamil al-Udhri (w. } \\
\text { 701M), } \\
\text { Umar Ibn Abu } \\
\text { Robi'ah (w. 719M), } \\
\text { dan } \\
\text { Al-Farasdaq (w. } \\
\text { 732M) }\end{array}$ & Sastrawan-sastrawan Arab & \\
\hline 3 & & $\begin{array}{l}\text { Harun al-Rasyid } \\
\text { (785-809 M) dan al- } \\
\text { Ma'mun (813-833 } \\
\text { M) }\end{array}$ & $\begin{array}{l}\text { Menterjemahkan } \\
\text { karya bahasa }\end{array}$ & \\
\hline 4 & & Khalifah al-Ma'mun & Membangun baitul hikmah & \\
\hline
\end{tabular}

Salah satu tokoh Islam yang berpengaruh dalam dunia kedokteran adalah Ibnu Sina (Avicenna) nama lengkapnya Abu Ali al-Husain Ibnu Abdallah Ibnu al-Hasan Ibnu Ali Ibnu Sina, lahir di Uzbekistan dan dikenal sebagai tokoh Islam yang mendalami banyak ilmu pengetahuan. Karyanya yang berjudul " the Canon" dijadikan sebagai standar textbook kedokteran baik di Timur Tengah ataupun Eropa. Orang-orang Barat lebih mengenal Ibnu Sina sebagai politikus dan bapak kedokteran Islam. Ibnu Sina mempelajari ilmu politik dari ayahnya sejak masih kecil, sedangkan ilmu kedokteran kebanyakan ia pelajari secara otodidak. Karya berikutnya adalah kitab asy-Syifa' (the Book of Heeling) yang didalamnya membahas tentang dasar-dasar dan metode dalam mencari kebenaran dalam ilmu pengetahuan, yang kemudian metode tersebut disempurnakan oleh Galileo. Dalam buku yang sama Ibnu Sina membuat hipotesa bahwa awal mula pembentukan gunung disebabkan oleh proses pergerakan bumi seperti 
pergerakan sungai dan gempa. Pada masanya, Ibnu Sina dikenal sebagai orang yang berpikir logis dan jauh kedepan. Gaya berpikirnya banyak dipengaruhi oleh ajaran Plato dan Aristoteles yang merupakan tokoh utama konsep filsafat logika yang membahas segala sesuatu sampai ke akarnya. Berikut merupakan karyakarya fenomenalnya: Qanun fi at-Tib (the Canon of Medicine), Asy-Syifa', arRisalah fi Ibtal Ahkam an-Nujum, dan Al-Hikmatul Masyriqiyah.

Dalam bidang kimia, Muhammad ar-Rozi (w. 925M) telah menggunakan alat-lat khusus untuk melakukan penelitian dengan langkahlangkah yang yang jamak dilakukan oleh ahli kimia, seperti: kalsinasi, distilasi, kristalisasi, dan sebagainya. Penemuan lain yang terkenal dari arRozi adalah benang fontanel (benang bedah). Ar-Rozi sebagaimana Ibnu Sina (Avicenna) juga terkenal sebagai pakar kedokteran dalam dunia Barat. Gambaran keduanya dapat ditemukan pada Fakultas Kedokteran Universitas di Paris. Karya-karyanya lebih terkenal dengan nama "Razes" di dunia Barat. Ibnu Haytam merupakan tokoh ulama' yang terkenal dengan teori optiknya. Dalam karyanya "Kitab al-Manadzir" Ibnu Haytam menjelaskan tentang teori optik dalam bidang fisika. Selain Ibnu Haytam, Al-Khoziny melalui karyanya "Kitab Mizanul Hikmah" memaparkan secara spesifik tentang gaya grafitasi.

Muhammad Ibnu Musa al-
Khawarizmi (w. 850M), merupakan tokoh Islam yang berperan dalam pengembangan penemuan angka nol (0) dan titik (.) selanjutnya, ia mengembangkan pendekatan khusus dalam memecahkan persamaan linier dan kuadrat atau yang lebih dikenal dengan aljabar. Teori aljabar ini ia jelaskan dalam karyanya yang berjudul Kitab al-Mukhtashar fi Hisab al-Jabar wal Muqabalah atau "Rangkuman Kalkulasi dengan Metode Melengkapkan dan Menyeimbangkan. Penemuan ini tentu sangat membantu untuk mempermudah proses penghitungan sekalipun dengan kelipatan atau jumlah yang banyak. Karya selanjutnya yang ia tulis adalah Kitab Zij al-Sindind yang menjelaskan tentang proses pergerakan matahari, bulan, dan planet-planet. Karyanya yang lain, yang merupakan karya terbesarnya adalah Kitab Surah al-Ard yang lebih dikenal dengan judul "Geography" dalam dunia Barat. Mengulas tentang keliling bumi melalui proyeksi gerakan matahari dan pendekatan matematis. Sebut saja, Abu Hasan al-Uqhdisy (w. 953M), dan Umar Ibn Khayyam (w. 1131M).

Selanjutnya, dalam bidang sosiologi, filsafat, dan sejarah, Abu Zayd Abdurrahman Ibnu Muhammad Ibnu Khaldun al-Khadrami populer sebagai bapak sosiologi modern. Berasal dari Tunisia orang-orang Barat mengenal Ibnu Khaldun sebagai pelopor dan perintis ilmu sosiologi 
modern. Kitab Muqoddimah merupakan karyanya yang terbesar dan populer. Sedangkan Abu Masyar alFalaki al-Balkhi merupakan salah satu tokoh Islam yang populer berkontribusi pada bidang astronomi. Karyanya diberi nama Kitab al-`Uluf yang membahas tentang ramalan-ramalan perbintangan.

Abu Yusuf Ya'qub Ibnu Ishaq alSabbah al-Kindi seorang filsuf muslim yang dipercaya oleh khalifa alMakmun untuk menjadi ketua tim penerjemah di Baitul Hikmah yang bertugas untuk menerjemahkan karyakarya filsafat yang berasal dari Romawi dan Yunani. Ia dikenal sebagai ilmuan muslim terbesar sepanjang sejarah. Selain menjadi ketua penerjemah ia juga turut melahirkan karya melalui tulisan yang mencapai 260 judul buku yang membahas berbagai disiplin ilmu. Dalam bidang fisika optik, ia menjelaskan bahwa agar mata bisa melihat benda, maka diperlukan objek yang bisa mengarahkan benda tersebut ke mata, dalam hal ini udara.

Nashiruddin at-Tusi merupakan tokoh muslim abad ke 13, ia merupakan salah satu tokoh yang juga menguasai banyak ilmu pengetahuan, seperti matematika, biologi, astronomi, kimia dan fisika. Salah satu kontribusinya dalam ilmu pengetahuan adalah tentang meknisme teori seleksi alam yang membentuk keanekaragaman hayati di bumi. Teori ini ia cetuskan 750 tahun sebelum
Charles Darwin dan Alferd Wallace. Ia menyebutkan bahwa organismeorganisme yang bermutasi lebih cepat akan lebih bervariasi dibandingkan individu lainnya. Faktor internal dan eksternal menjadi sebab perubahan tersebut. Dari sinilah pemikiran manusia tentang asal mula spesies terbentuk. Selain dalam ilmu pengetahuan at-Tusi juga berkontribusi dalam menyelamatkan 400.000 buku di Baitul Hikmah dalam misi penghancuran dan serbuan Mongol. Ia membawa buku-buku tersebut ke Azerbaijan dan diletakkan di Observatorium Maragheh. Setelah proses pemindahan buku-buku ke Maragheh ia melanjutkan risetnya tentang pergerakan bumi. Tiga abad kemudian, risetnya menjadi inspirasi bagi Nicolas Copernicus, yang membuktikan bahwa bumi berputar mengelilingi matahari.

Abul Fath Umar bin Ibrahim alKhayyam merupakan tokoh Islam yang mahir dalam matematika, sastra, dan astronomi. Ia lahir di Nishapur Iran. Sumbangan terbesarnya dalam bidang matematika adalah segi empat khayyam saccheri. Ia juga merupakan orang pertama yang menjelaskan secara lengkap konsep segitiga pascal atau disebut "segitiga khayyam pascal" oleh banyak ahli matematika. Dalam bidang astronomi, ia menjelaskan bahwa bumi berputar pada sumbunya. Bukunya " Rubaiyat of Omar Khayyam" merupakan karyanya dalam 
bidang sastra yang sangat fenomenal dalam berbagai bahasa.

dan sudah banyak diterjemahkan

Tabel 3 Konstribusi Tokoh Islam dalam Sains

\begin{tabular}{|c|c|c|c|c|}
\hline No & $\begin{array}{l}\text { Bidang } \\
\text { Sains }\end{array}$ & Tokoh Islam & Bentuk Kontribusi & Karya \\
\hline 1 & Matematika & $\begin{array}{l}\text { Muhammad } \\
\text { Ibnu Musa al- } \\
\text { Khawarizm (w. } \\
\text { 875M), } \\
\text { Abul Hasan al- } \\
\text { Uqdisy (w. } \\
\text { 953M), Umar } \\
\text { Ibnu Khayyam } \\
\text { (w. 1131M). }\end{array}$ & Penemuan Aljabar & $\begin{array}{l}\text { Kitab al-Jam'a } \\
\text { wal Tafriq bil } \\
\text { Hisab al-Hindi }\end{array}$ \\
\hline 2 & Astronomi & $\begin{array}{l}\text { Abu Masyar al- } \\
\text { Falaki al-Balkhi }\end{array}$ & $\begin{array}{l}\text { Membuat ramalan- } \\
\text { ramalan perbintangan }\end{array}$ & Kitab Al'Uluf \\
\hline 3 & Fisika & $\begin{array}{l}\text { Ibn Haytam dan } \\
\text { Al-Khoziny }\end{array}$ & $\begin{array}{l}\text { 1. Mengembangakan } \\
\text { teori optik } \\
\text { 2. Gaya grafitasi }\end{array}$ & $\begin{array}{l}\text { "Kitab al- } \\
\text { Manadzir", } \\
\text { "Kitab Mizanul } \\
\text { Hikmah }\end{array}$ \\
\hline 4 & Kimia & $\begin{array}{l}\text { Ar-Rozi (w. } 925 \\
\text { M) }\end{array}$ & $\begin{array}{l}\text { Penggunaan peralatan } \\
\text { laboratorium kimia dan } \\
\text { Penemu benang fontanel }\end{array}$ & "Razes" \\
\hline 5 & Kedokteran & 1. Ar-Rozi & & $\begin{array}{l}\text { Karya populer: } \\
\text { Asy-Syifa', } \\
\text { Al-Hikmatul } \\
\text { Masyriqiyah, } \\
\text { Al-Qanun fi at- } \\
\text { Tib (the Canon } \\
\text { of Medicine), }\end{array}$ \\
\hline 6 & $\begin{array}{l}\text { Sosiologi, } \\
\text { sejarah, dan } \\
\text { filsafat }\end{array}$ & Ibn Khaldun & $\begin{array}{l}\text { pakar di bidang sosiologi } \\
\text { modern }\end{array}$ & Muqaddimah \\
\hline
\end{tabular}

Kemampuan tokoh-tokoh muslim pada masa klasik dalam memberikan sumbangan pemikiran dan penemuan dalam bidang sains tidak terlepas dari ajaran-ajaran Islam profetik yang dibawa nabi Muhammad saw. Ini menunjukkan bahwa kemampuan bergerak untuk maju dan tumbuh komunitas Islam klasik berkaitan dengan ajaran Islam yang paling autentik yaitu al-Qur'an dan Hadist. Namun demikian, tidak dapat dipungkiri bahwa peradaban keilmuan Islam juga mendapat pengaruh dari ilmu-ilmu terdahulu warisan dari 
Yunani, China, Romawi, India, dan Persia.

\section{KESIMPULAN}

Pertumbuhan Islam ikut serta mewarnai pertumbuhan peradaban dunia baik dalam seni dan sains. Bahkan pesatnya pertumbuhan Islam diakui sangat cemerlang dan merupakan sebuah peradaban yang paling berpengaruh. Bentuk kontribusi Islam dalam bidang seni oleh Imam Ghozali membahas tentang hukum seni itu sendiri yang dituangkan dalam magnum opusnya Ihya' 'Ulumuddin. Qais bin alMulawwah, Jamil al-Udhri , Umar Ibn Abu Robi'ah, dan Al-Farasdaq merupakan tokoh-tokoh yang berpengaruh dalam perkembangan sastra Arab. Sedangkan dalam bidang sains ada al-Khawarizmi dengan penemuan aljabarnya dalam kitab al-Jam'a wal Tafriq bil Hisab al-Hind, alFalaki dengan ramalan-ramalan perbintangan dalam kitab al-`Uluf, Ibnu Haytam dan al-Khoziny dengan teori optik dan gravitasi dalam kitab al-Manadzir dan Mizanul Hikmah, ar-Razi penemu benang fontanel, Ibnu Khaldun dalam bidang sosiologi modern dengan karya kitab Muqaddimah, dan Ibnu Sina dalam bidang kedokteran dalam kitab Qanun fi at-Tib.

\section{DAFTAR PUSTAKA}

Leaman, Oliver. (2005). Estetika Islam: Menafsirkan Seni dan Keindahan. Bandung: Mizan.

Shihab, M. Quraish. (1996). Wawasan AlQur'an. Bandung: Mizan.

Surajiyo. (2007). Suatu Pengantar Ilmu Filsafat. Jakarta: PT. Bumi Aksara.

Al-Ghazali, Abu Hamid Muhammad bin Muhammad. (tt.). Ihya Ulumuddin, Libanon: Dar Al-Fikr.

Nawawi, Mohammad. (tt.). Syarh Sulam alTaufik, Surabaya: Dar Ihya al-Kitab
al-Arabiyyah.

Salim, Mohammad bin. (tt.). Is'adu al-Rafik wa Bughyatu al-Syiddiq, Surabaya: Dar Ihya al-Kitab al-Arabiyyah.

\section{Terjemahan}

Nashr, Sayyed Hossein. (1993). Spiritualitas dan Seni Islam. Terj. Sutejo. Bandung: Mizan.

Qardhawi, Yusuf. (1998). Islam Bicara Seni. terj. Wahid Ahmadi, dkk. Solo: Intermedia.

\section{Artikel Jurnal}

Rizali, Nanang. (2012). Kedudukan Seni dalam Islam. Jurnal Tsaqafah, vol. 1 no. 1 . Hlm. 17 